\title{
Research on Current Situation and Existing Problems of Coal Resources Development and Utilization in India
}

\author{
WANG Guangqiang ${ }^{1, ~ a, ~ L I ~ Z e n g ~}{ }^{2, b}$ \\ ${ }^{1}$ College of Geoscience and Surveying Engineering, China University of Mining \& \\ Technology,Beijing, Beijing, P.R.China, \\ ${ }^{2}$ College of Geoscience and Surveying Engineering, China University of Mining \& \\ Technology,Beijing, Beijing, P.R.China,

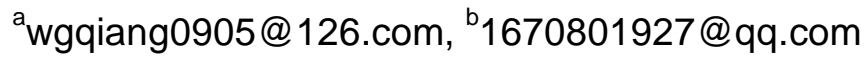

\begin{abstract}
Keywords: Coal resources, Development and utilization status, Import and export trade
Abstract. Coal is an important pillar of energy security and sustainable economic development in India. India is rich in coal resources, the rapid growth of coal demand was led with the rapid development of its economy in recent years. On the basis of systematic analysis of characteristics of coal resources, development and utilization status, the situation of export and import, points out some existing problems in the development process of India coal industry, this will provide some scientific basis for India coal production and consumption in the future.
\end{abstract}

\section{Introduction}

Republic of India is located in southern Asia while is bounded by Bangladesh, People's Republic of China, Nepal and so on.India is the largest country in the South Asian subcontinent, land area ranks seventh in the world. India is located in the middle of the South Asian subcontinent, the center of India plate, its geological framework is clear,Himalaya fold belt is located in the northern while India Peninsula craton located in the middle and southern with piedmont deep between them.Most coal resources in India develop in the Singh Blom Craton and the secondary craton of the India Peninsula craton.The Carboniferous Permian in the Gondwana rock series is the main coal bearing.

The coal is divided into two types of black coal and lignite in India. The distribution of rich coal resources in India has the following basic characteristics:(1) Coal resources in the Late Carboniferous Permian belongs to the black coal with the dominant position of coal resources quantity, was mainly distributed in 27 main coal fields located at the eastern and southern central of India Peninsula.(2) Production area of Neogene Period coal is located in the northeast India.(3)Tamil Nadu in southern India produces lignite.(4) Coking Coal is mainly located in the Damodar-koel in the the middle north region of India. ${ }^{[1-3]}$

\section{Development and utilization status}

Development status.In 2013, India has proven coal reserves of about 96 billion tons which is the world's fifth largest reserves.Coal reserves in the anthracite and bituminous ranked third in the world just behind the United States and Chinese. India's proven coal reserves are more than 139 billion tons in 2014. Most coal reserves are located in the eastern part of the country.Coal reserves in Harland, Chattisgarh and Aisha three areas accounting for about 2/3 of the country.Other important coal production bases including Bengal, Andhra Pradesh, Madhya Pradesh, Maharashtra and other regions. The distribution of major coal mines in India is shown in Fig.2.1. 


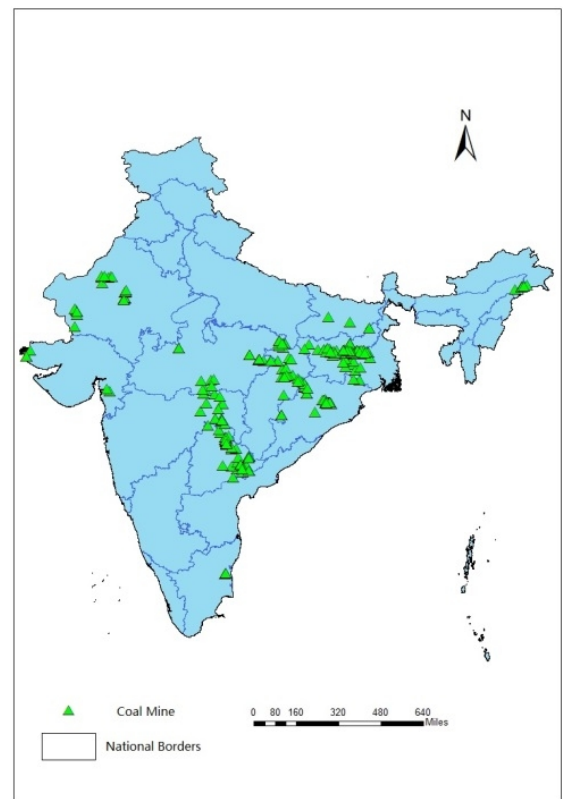

Fig. 2.1 Distribution map of main coal mines in India

India is the world's third largest coal production base on the scale,coal output reached 67 billion and 500 million tons in 2013 nearly doubled two times as in 2000.Almost all Coal produced in India was used to meet the needs of domestic production.Coal production increased at an annual rate of $9 \%$ in 2104. Meanwhile, preliminary estimates report points out that CIL(Coal India Limited) company annual output growth will be more than $9 \%$ in 2015.In 2015,India issued a goal to stimulate coal production, coal production will reach 1 billion and 700 million tons by 2020 which is nearly three times of the output in 2013.CIL will reach $2 / 3$ of the target while the private sector and small mines will make up for the remaining 1/3. Although India intends to reduce regulatory authorities, reduce supervision, improve production efficiency, to achieve this goal is still a serious challenge ${ }^{[4]} .2009-2014$ annual coal production and annual consumption is shown in Fig.2.2 and 2.3.

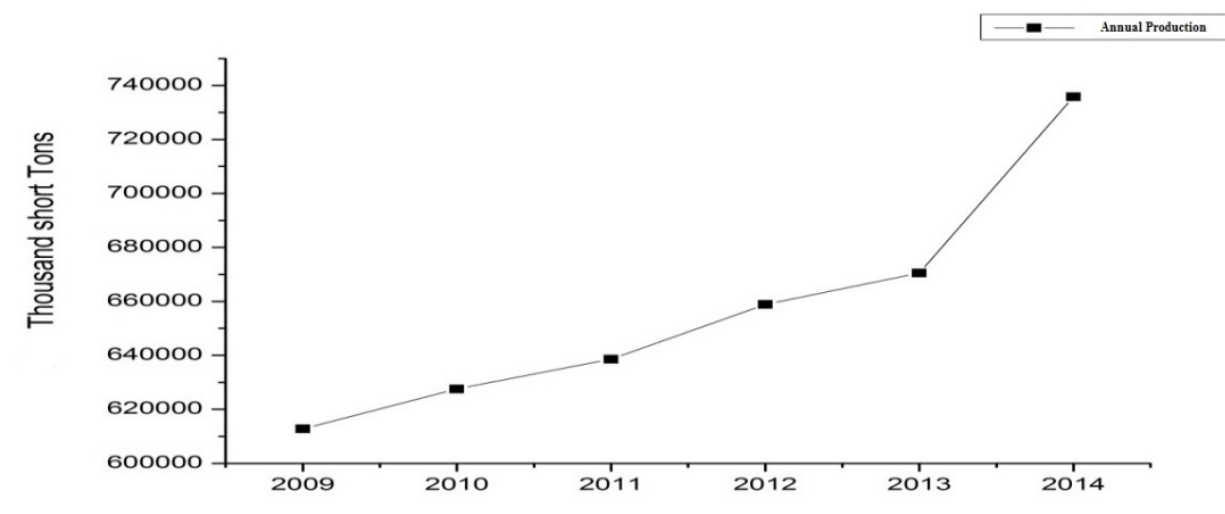

Fig. 2.2 2009 -2014 annual coal production

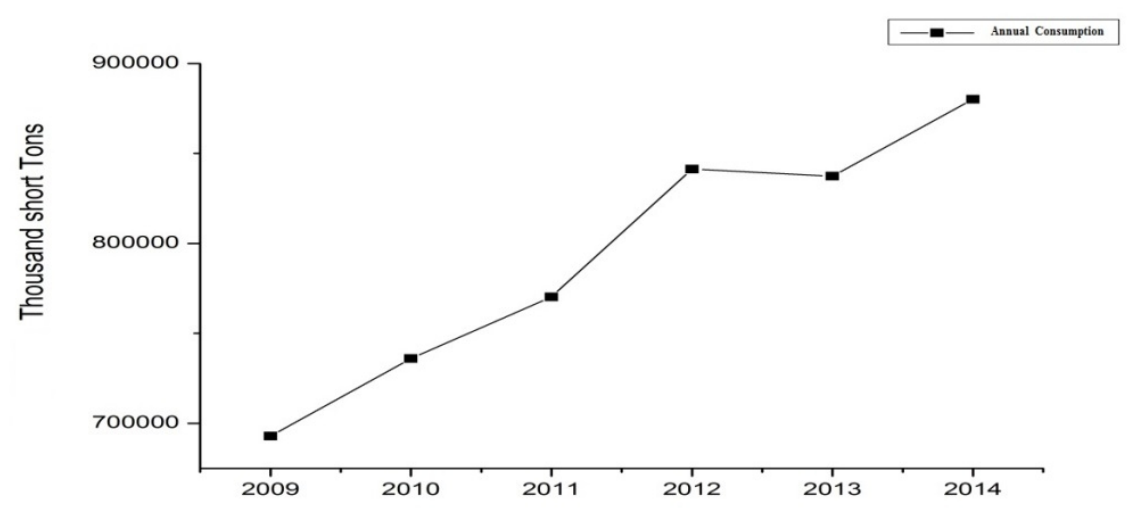

Fig. 2.3 2009 -2014 annual coal consumption 
Utilization status status.According to the 2014 survey, it was found that the electricity sector is the largest coal consumption sector, accounting for about $65 \%$ of coal consumption.Because the power plants rely heavily on coal, coal shortage is the main factor leading to the national power shortage or even blackouts.In recent years, the power industry began to seek natural gas supply,but the natural gas supply needs to take into account the different seasons with numerous influencing factors, the development of electric power industry demands continuous improvement of coal quality.India issued a national coal distribution strategy to provide good coal pricing to meet the greater demand for coal in 2007.

Steel and cement industries are also important consumers of coal.Coking coal is an important raw material of iron and steel production, but limited reserves restricting the development of India iron and steel industry.India needs a lot of imported coking coal to meet the needs of the entire industry ${ }^{[5]}$.

India 2009-2013 total primary energy production and consumption is shown in Fig.2.4 and Fig.2.5.As can be seen from the figure,primary energy output showed a growing trend from 2009 to 2012, mainly because a large number will be used to meet the need of industrial development.Primary energy output showed a straight decline from 2012 to 2013,mainly because a large number of imported energy from abroad to ease the domestic production pressure. The total amount of disposable energy consumption continues to show an upward trend from 2009 to 2013, and will continue to rise expected to 2020 .

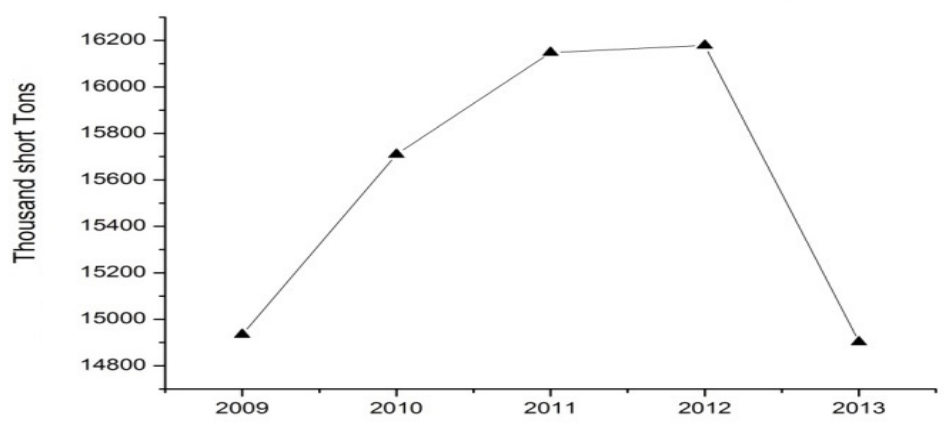

Fig. 2.4 2009-2013 total primary energy production

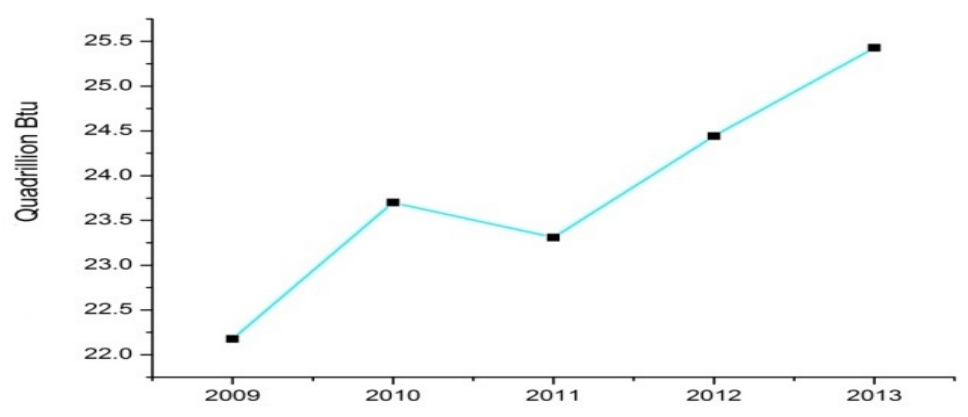

Fig. 2.5 2009-2013 total primary energy consumption

Overview of import and export. Although the coal industry in India has been rapid development in recent years, but the demand for domestic coal consumption is also expanding, the contradiction between supply and demand of coal has not been solved.Therefore, India as a coal resources big country still needs to import coal to meet domestic demand.It is therefore necessary to import coking coal from Australia to meet the needs of steel mills and import power coal from South Africa and Indonesia to supply electricity and cement production just because of India coal generally with high ash content and low thermal value.Coal imports growth rate faster than expected growth.If coal prices continue to remain low, India coal imports in the next three to four years will maintain a rapid growth ${ }^{[6]}$.

In terms of coal imports,India imports of coal showed a rising trend from 2009 to 2014 while coal 
exports showed a downward trend in general during the past five years. A short period of large export coal phenomenon was appeared from 2010 to 2011,but coal exports fell rapidly from 2011 to 2012, coal exports showed a downward trend during the period of 2012 to 2014, the main coal exports after the forecast will continue to show a downward trend. The overall trend in coal trade is the import trade volume will continue to grow while export trade volume will continue to decline.2009-2014 annual import volume and export volume is shown in the Fig.2.6 and Fig.2.7.

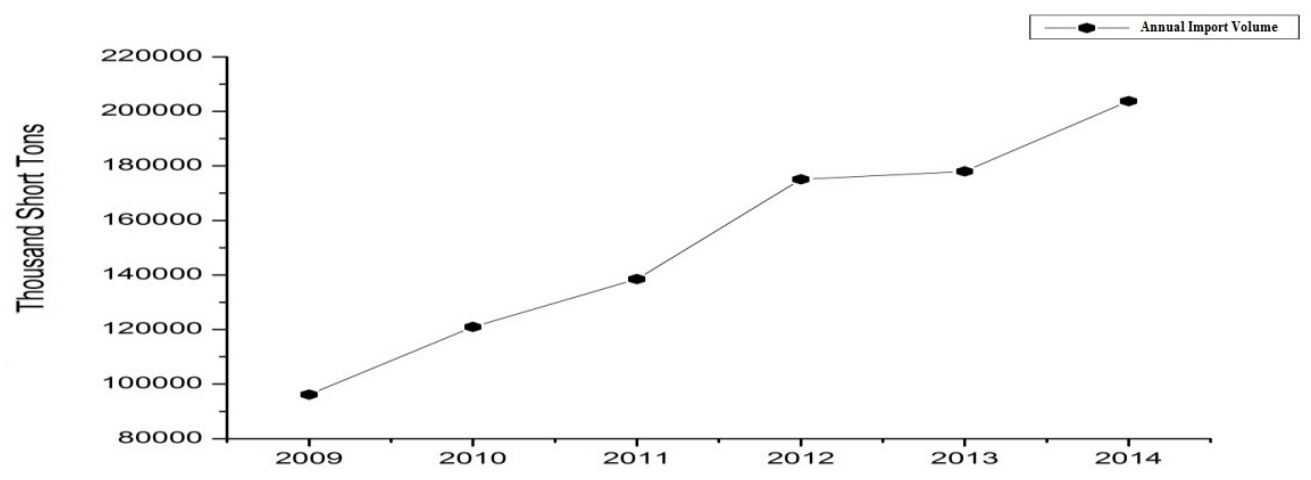

Fig. 2.6 2009-2014 annual import volume

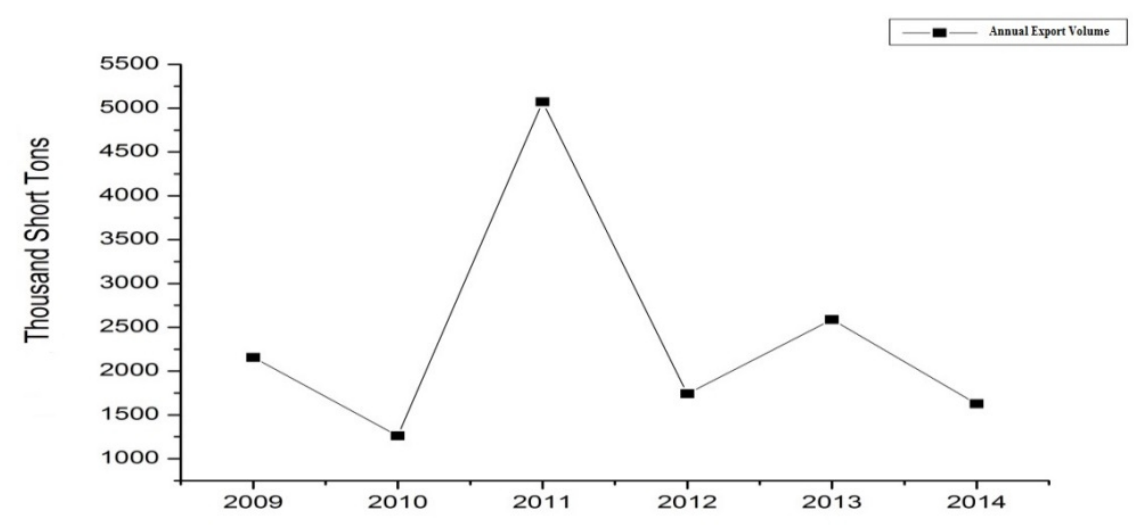

Fig. 2.7 2009-2014 annual export volume

Although India is not the main importer of coal in the past,India had already imported coking coal more than and 20 years to meet the needs of the steel industry.India's recent shortage of coal and coking coal for power generation had prompted India's coal imports to increase substantially over the past few years.In 2015, India purchased 2,26 million tons coal from overseas and had become the world's largest coal importer country.Indonesia is India's largest source of coal imports, accounting for $52 \%$ of total coal imports.

\section{Existing problems}

(1)Although the quantity of coal resources in India are abundant, the ash content is too high, which leads to the low thermal efficiency, high utilization cost and large environmental pollution.

(2)Despite considerable reserves and production increases, India is still facing a severe situation of insufficient supply and mining industry.About $90 \%$ of the country's coal mine is opencut coal mine,surface coal mine and shallow mine which is less than 1000 feet deep,although this is more effective and more safety than underground coal mining, it caused more negative environmental impact.Productivity in India is at a low level because of lack of advanced technology for large underground mining operations.Lack of competition within the coal industry and inhibition of private enterprises and foreign investment can not improve the underground mining technology ${ }^{[7]}$.

(3)Although coal production in recent years increased by about $5 \%$ yearly,had not been able to effectively solve the gap between supply and demand.Because coal output can not keep up with demand,especially in the power industry,India faces more coal demand and import problems. 
(4)Most of the coal transportation in India mainly uses railway transportation, while the railway transportation capacity is limited, the high transportation cost and other factors restrict the production and use of India coal.

\section{Conclusions and recommendations}

The rapid industrialization stage in India is bound to consume a large amount of mineral resources. The existing problems in the development of coal industry will inevitably make the development of coal resources difficult to meet the rapid development of the future economy driven by a large increase in consumption of resources.It is recommended to take corresponding measures to improve coal production capacity and recovery;Currently only government departments in India can carry out commercial trading of coal,private trading should be considered in order to meet the development needs;Government departments need to set up special funds to support overseas mergers and acquisitions to meet domestic demand for resources ${ }^{[8]}$;Measures should be taken to strengthen research and exploration behavior and strengthen infrastructure construction.

\section{References}

[1]Daxiao Dong,Xinxu Su.Coal Resources in India.Coal Grology of China,2016(8):38 41.In Chinese

[2]Jianhua Zhang,Liangshi Wu.Main mineral Resources and Its Geological Characteristics in Republic of India.Mineral Deposits, 2008,27(4):541 543.In Chinese

[3]Gireesh R,Pandey D K.Basement Geology along Southwest Indian Margin.Petroleum Exploration and Development,2014,41(1):62 66

[4]Shanglin Li,etc.Geological Characteristics of Dominant Mineral Resources in India.Advances in Earth Science, 2012,27:491 493.In Chinese

[5]Kale S S,Mazaheri N.Natural resources, development strategies, and lower caste empowerment in India' s mineral belt.St Comp Int Dev,2014(49):343 369

[6]Fengbin Xie.The Current Situation and Analysis of India' s Mineral Resources.China Mining Magazine,2013, 22(8):14 17.In Chinese

[7]Xifeng Chen,Jinhua Ye.Actuality of India's Mineral Resources Development and Its References.Resources and Industries, 2015,17(6):73 81.In Chinese

[8]Sahoo A K,Sahoo D,Sahu N C.Mining export,industrial production and economic growth:A cointeration and causality analysis for India.Resources Policy,2014(42): 27 34 